\title{
Factors Determining Market Supply of Chickpea in Gondar Zuria Woreda, ANRS, Ethiopia
}

\author{
Jemberu Tarekegn Asmare ${ }^{1, ~}$, Bosena Tegegne Delele ${ }^{2}$, Daregot Berihun Tenessa ${ }^{3}$ \\ ${ }^{1}$ Department of Agricultural Economics, Jinka University, Jinka, Ethiopia \\ ${ }^{2}$ School of Agricultural Economics and Agribusiness, Haramaya University, Haramaya, Ethiopia \\ ${ }^{3}$ Faculty of Business and Economics, Bahirdar University, Bahir Dar, Ethiopia

\section{Email address:} \\ tarekegnasmaer@gmail.com (J. T. Asmare), bosenat@gmail.com (B. T. Delele), daregotbdu@gmail.com (D. B. Tenessa) \\ ${ }^{*}$ Corresponding Author
}

\section{To cite this article:}

Jemberu Tarekegn Asmare, Bosena Tegegne Delele, Daregot Berihun Tenessa. Factors Determining Market Supply of Chickpea in Gondar Zuria Woreda, ANRS, Ethiopia. Science Journal of Business and Management. Vol. 7, No. 1, 2019, pp. 1-7.

doi: 10.11648/j.sjbm.20190701.11

Received: December 25, 2018; Accepted: January 16, 2019; Published: January 30, 2019

\begin{abstract}
Chickpea is important for its contribution to enhance food security and as source of cash income for a large proportion of the rural households ever. Among the pulses growing in the Woreda, Chickpea is the major crop both in terms of volume of production and area cultivated. It is also the major source of cash income to the farmers among the crops grown in the area. However, enhancing chickpea farmers to reach markets is a key issue needed in the study area. This study was aimed to analyze factors determining market supply of chickpea at farm household level using the data collected from randomly selected 123 farmers. The data collected was analyzed using descriptive statistics and Robust Ordinary Least Square regression model. The results of econometric analysis showed that productivity of chickpea, size of land allocated for chickpea production, lagged price, education level of household head and year of experience in chickpea production of the household head positively and significantly affected chickpea market supply at farm household level. Based on the study results, policy interventions like encouragement of the concerned body to increase the productivity of chickpea, strengthening access to education, strengthening trainings are required.
\end{abstract}

Keywords: Chickpea, Ethiopia, Farm, Market Supply, Regression Analysis

\section{Introduction}

Ethiopia has a suitable climatic and edaphic conditions for the production of good quality Desi and Kabuli chickpeas. It has the area coverage of $282,216.28$ ha and production of $4,963,027.78$ quintals in the Country [1]. The country is the largest producer of chickpea in Africa accounting for about $46 \%$ of the continent's production during 1994-2014. It is also the fifth largest producer worldwide and contributes about $3.2 \%$ to the total world chickpea production [2].

Chickpea (Cicerarietinum), locally known as shimbra, is one of the major pulse crops (including faba bean, field pea, haricot bean, lentil and grass pea) in Ethiopia and in terms of production it is the second most important legume crop after faba beans. It contributed about $17.6 \%$ of the total pulse production during 2014. The total annual average (1999-2014) chickpea production is estimated at about 260 thousand tones [2].

Average annual growth rate in area and production showed that cultivated area under chickpea and production in Ethiopia increased by $2.1 \%$ and $7.6 \%$, respectively during the same period. The production growth rate is relatively higher compared to faba beans $(5.7 \%)$. Grain yield of chickpea has also showed upward trends, particularly starting from the year 2004 and onwards, with an average annual growth rate of $5.9 \%$. Most of the chickpea is cultivated under rain fed conditions [3].

Among the pulses growing in the Woreda, Chickpea is the major crop both in terms of volume of production and area cultivated. It is also the major source of cash income to the farmers among the crops grown in the area. On the demand side, chickpea continue to be an essential crop commodity for food security. 
Despite its major producing area, important inputs, such as, fertilizer, improved seed and chemical are either unavailable or prices are usually high making them very expensive and unprofitable to farmers to use. Limited resources, lack of adequate infrastructure and institutions that support agricultural development are the major factors behind low productivity of small scale agriculture in Ethiopia that lead to production patterns dominated by the satisfaction of subsistence requirements and food insecurity at both household and national levels [4].

Farmers in Gondar Zuria woreda practice mixed farming and crop production, which is an important component of the farming system. In order to benefit chickpea farmers from production and market supply, chickpea marketing system must operate efficiently. In this study factors determining Chickpea market supply in the study area was analyzed to provide information for interventions in the future.

\section{Research Methodology}

\subsection{Description of the Study Area}

The study was conducted in Gondar Zuria Woreda. Gondar zuria is one of the 114 Woredas in the Amhara National Regional State (ANRS) of Ethiopia and 16 Woredas of North Gondar Zone. Part of the North Gondar Zone, Gondar Zuria Woreda is bordered on the south by the Debub Gondar Zone, on the southwest by Lake Tana, on the west by Dembiya, on the north by Lay Armachiho, on the northeast by Wegera, and on the southeast by Mirab Belessa [5]

The study area is located $728 \mathrm{~km}$ North of Addis Ababa, the capital city of Ethiopia. Geographically, it is located at $37^{\circ} 24^{\prime} 24^{\prime \prime} \mathrm{E}-37^{\circ} 45^{\prime} 43^{\prime \prime} \mathrm{E}$ and $12^{\circ} 7^{\prime} 23^{\prime \prime} \mathrm{N}-12^{\circ} 39^{\prime} 24^{\prime \prime} \mathrm{N}$ and its total area is $1286.76 \mathrm{~km}^{2}$. The woreda is sub divided in to 35 rural and 2 urban kebeles for development and administration purpose [5].

\subsubsection{Agro-Climatic Environment}

Gondar Zuria Woreda is located at 1107-3022 m a.s.1, and falls in to three agro ecological zones. The two agro ecology zones, Weynadega (1500-2300 m a.s.l) and Dega (2300-3200 $\mathrm{m}$ a.s.1.) constitute the largest area coverage as compared to the Kolla that falls in the range of 500-1500 ma.s.l. In the woreda, temperature ranges between $14-20^{\circ} \mathrm{C}$ with the mean annual temperature of $17.9^{\circ} \mathrm{C}$. Rainfall ranges between 1030 $1223 \mathrm{~mm}$ with the mean annual rainfall of $1100 \mathrm{~mm}$ [6].

\subsubsection{Production System}

People in Gondar Zuria Woreda are mainly involved in agriculture as their main job. The production system is mainly depending on seasonal rain and irrigation which enables the farmers to produce twice per year. Three years later new methods of production are being introduced like planting in rows and provision of quality seeds [7]. The major land use and land cover types observed in the Woreda are arable /crop land $(42.21 \%)$, pasture (7\%), forest and shrub land $(41.11 \%)$, and the remaining $9.68 \%$ is considered as a degraded or other land. Chickpea, Teff, corn, sorghum, barley, wheat, maize, potato, onion, garlic and millet are the important cash crops. The town of Maksegnit and Tseda serves as an important market center of the Woreda. The economy of the Woreda is predominantly agricultural production based commodity [7].

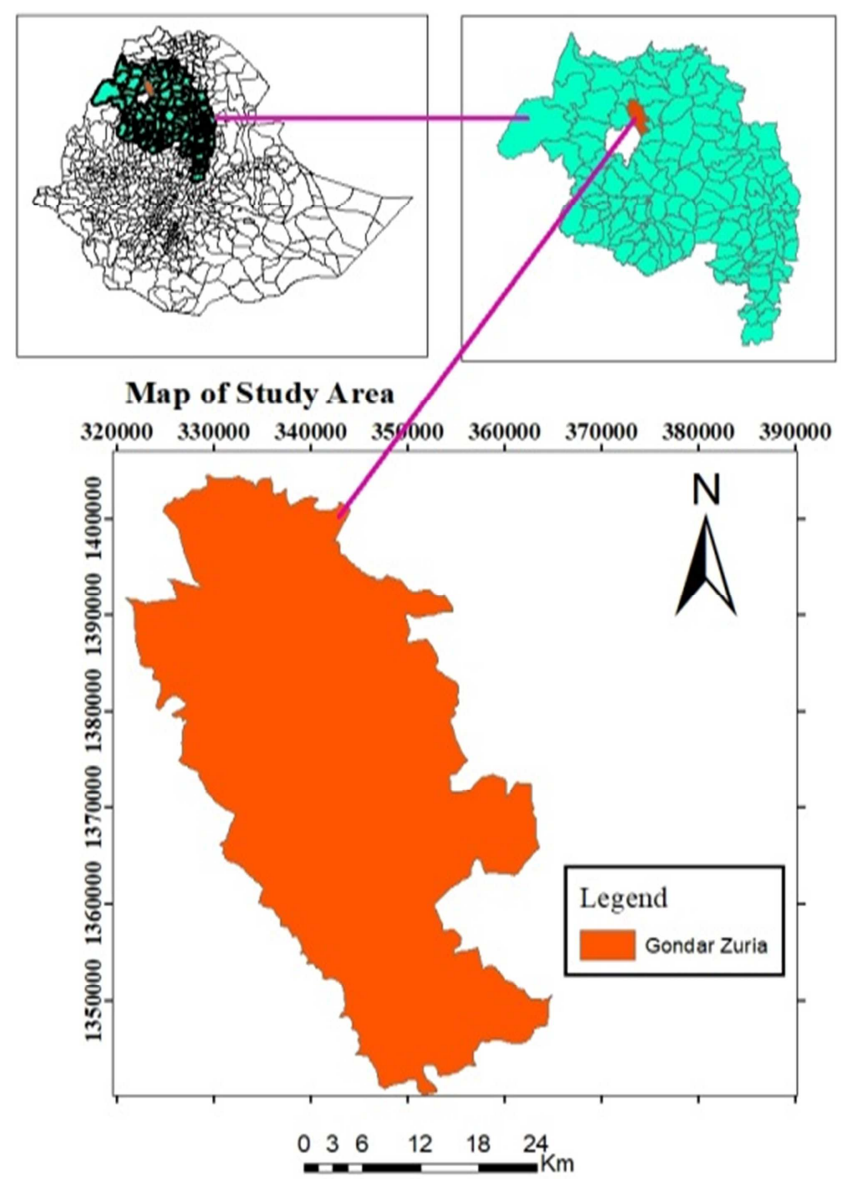

Figure 1. Geographical location of the study area.

\subsection{Data Types, Sources and Method of Data Collection}

Both primary and secondary data were used for this study. The formal survey was applied through interviews with the selected chickpea producer farmers using a pre-tested questionnaire and focus group discussion. Secondary data was collected from published, unpublished documents, and internet sources.

\subsection{Sampling Techniques and Sample Size Determination}

The study area, Gondar zuria woreda was selected as a target area since the area is the major chickpea producing and marketing area. For the sampling of producers, a two stage sampling procedure was applied. The woreda has 37 kebeles, 30 of them produce chickpea. In the First stage all chickpea producer kebeles in the woreda were selected purposively. In the second stage, from these chickpea producer kebeles, 5 sample kebeles were selected randomly. Thus, from each sampled kebele chickpea producer farmers were listed out with the help of development agents at kebele level. From these population 
lists sample farmers were selected randomly based on probability proportional to size sampling technique.

The total sample size for this study was determined based on the sampling formula provided by Yamane [8]. The formula used for the sample size determination with 95\% confidence level, 5\%( 0.9) degree of variability was:

$$
n=\frac{N}{1+N\left(e^{2}\right)}
$$

Where: $\mathrm{n}=$ sample size, $N=$ population size, and the level of precision. Based on the above formula the totals of 123 households were interviewed.

Table 1. Sample Chickpea Farmers.

\begin{tabular}{lll}
\hline $\begin{array}{l}\text { Name of the } \\
\text { villages }\end{array}$ & $\begin{array}{l}\text { Chickpea producer } \\
\text { households }\end{array}$ & Sample households \\
\hline Lemba & 6633 & 27 \\
Tsion-seguaji & 3618 & 15 \\
Tachi-Tseda & 8441 & 34 \\
Hamisa-Fuji & 6331 & 26 \\
Layiye & 5126 & 21 \\
Total & 30149 & 123 \\
\hline
\end{tabular}

\subsection{Methods of Data Analysis}

Both descriptive statistics and Econometrics analysis were used to analyze the data collected from chickpea Producers. Descriptive statistics was used to describe the characteristics of the household. Econometrics analysis was used for analyzing factors that determine market supply of chickpea at the farm household level in Gondar Zuria Woreda. Robust OLS regression analysis was applied. Econometric model specification of market supply function in matrix notation is the following.

$$
Y=X^{\prime} \beta+U
$$

Where: $\mathrm{Y}$ is quantity of chickpea supplied to the market, $\mathrm{X}^{\prime}$ is a vector of explanatory variables,

$\beta$ is a vector of parameters to be estimated and

$\mathrm{U}$ is disturbance term.

Quantity of chickpea supplied to the market is a continuous dependent variable used in the multiple linear regression model. It is measured in quintal and represents the supply of chickpea by farm households to the market in the year 2015/16.

\section{Results and Discussions}

This chapter presents the major findings of the study and discussions. Both descriptive and econometric model were used to analyze the primary data. Descriptive statistics was employed to describe the general demographic, socioeconomic and institutional characteristics of sample chickpea producer farmers in chickpea marketing chain are analyzed and discussed. Econometric analysis was used to identify factors determining at farm household level supply of chickpea to the market in Gondar Zuria Woreda.

\subsection{Socio-Economic Characteristics of Sampled Farm Households}

This sub-section explains the profile of sampled respondents with regard to their sex, family size, experience, level of education, access to extension services, access to market information and distance from main market.

Sex of respondent: Sample size of chickpea producer households considered during the survey was 123. As shown in Table 2, out of total household heads interviewed $73.17 \%$ were male headed households while $26.83 \%$ were female headed households (Table 2).

Education level of the household heads: from the total sampled household heads, the educational level of 56.91 percent were illiterate, 39.83 percent attend primary school education, 2.43 percent of them attended secondary education, and 0.8 percent of them attended college /university education. The grade completed of the respondent was considered in the analysis (Table 2).

Chickpea production experience, religion and marital status of the sample households: The respondents have an average of 32.14 years farming experience in chickpea production with standard deviation of 12.18. Out of the total respondents, 67.49, 26.01 and 6.5 percent were Orthodox Tewahido, Muslim and Protestant respectively. This indicates that the majority of the respondents were followers of Orthodox Tewahido. Concerning the marital status of the sample households most of the household heads (95.9\%) were married about 3.25 percent divorced household heads and 0.8 were single (Table 2 ).

Table 2. Distribution of sampled respondents by sex, education, religion, marital status and production experience.

\begin{tabular}{lll}
\hline Variable & N & \% \\
\hline Sex & & 73.17 \\
Male & 90 & 26.83 \\
Female & 33 & 56.91 \\
Education & & 39.83 \\
Illitrate & 70 & 2.43 \\
Attend primary school(1-8) & 49 & 0.8 \\
Attend secondary school(9-10) & 3 & \\
Attend college/Uni education & 1 & 67.49 \\
Religion & & 26.01 \\
Orthodox Tewahido & 83 & 6.5 \\
Muslim & 32 & 8 \\
Protestant & 8 & \\
Marital status & & \\
\hline
\end{tabular}




\begin{tabular}{|c|c|c|c|c|}
\hline Variable & $\mathbf{N}$ & & $\%$ & \\
\hline Married & 118 & & 95.9 & \\
\hline Divorced & 4 & & 3.25 & \\
\hline Single & 1 & & 0.8 & \\
\hline & Mean & S.D & Minimum & Maximum \\
\hline Experience in chickpea production & 32.14 & 12.18 & 20 & 65 \\
\hline
\end{tabular}

Source: Own survey result, 2016.

\section{Access to Institutional Service of the Farm Households}

Frequency of extension contact

Frequency of extension contact was also expected to have direct influence on the production and marketing of chickpea of farmers. In order to give effective extension service to the farmers the region assigned three DAs in each Kebele. The DAs are graduates of different ATVET colleges and Universities specializing in four agricultural streams such as fishery wet land and wildlife management, crop production, animal husbandry and natural resource management. For the frequency of extension contact $52 \%$ the sampled farmers reported that they have been receiving extension contact out of which $90.3 \%$ received advice about chickpea production and supply. The extension workers also visit farmers in different intervals. Some farmers were being visited more frequently while others have got no chance at all to be visited by the extension workers. To this end, the government has been attempting to fill the required knowledge gap and achieve food self-sufficiency in the country by placing at least three development agents (DAs) in each Kebeles and building Farmers Training Center (FTC). The Kebele level development agents are important means of transferring new agricultural technologies and improving farmers' capacity for innovations. The effort to disseminate new agricultural technologies is influenced by the efficiency of communication between the development (change) agent and the farmers at grass roots level. The survey result indicated that the average frequency of extension contact of the sampled households was 1.37 times with the standard deviations of 2.12 (Table 3).

Table 3. Frequency of extension contact of the sampled household heads.

\begin{tabular}{lllll}
\hline Variable & Mean & S.D & Minimum & Maximum \\
\hline Number of extension contact & 1.37 & 2.12 & 0 & 10 \\
\hline
\end{tabular}

Source: Own survey result, 2016.

Access to credit service: finance is the crucial element that can be used for running the production and the marketing of the product. As depicted in Table 4, only $34.96 \%$ of sampled producers had access to credit in Gondar Zuria Woreda. Access to credit is one way of improving smallholder farmers' ability of chickpea production and productivity. The main objective of the credit was to purchase improved chickpea seed (78.6\%) and pesticides (21.4\%). Farmers with access to credit may minimize the effect of financial constraints and able to buy the necessary inputs which improves their chickpea productivity more readily than those with no access to credit. Therefore, it is expected that access to credit can increases the production of agricultural crops in general and chickpea in particular in the study area, demand for credit depends on availability of cash on hand. Sample chickpea producer farm households accessed credit from formal institutions (banks, MFI, and cooperatives) and informal sources (friends, relatives or village money lenders) (Table 4) Access to market information: with respect to access to market information there is no system in place for systematically collecting, analyzing and disseminating information relevant to the needs of different actors. Farmers have limited information on price prevailing even in the nearby markets. It is assumed that producers and traders with access to market information can make better decision on how much to produce and supply to the market. However, there was no organized market information system to support farmers in the study area. About $43.9 \%$ of the sampled farmers had access to market information from different sources and $56.1 \%$ had no access to market information. The type of information provided was about output price information. About $18.7 \%$ producers obtained market information from the nearby market, about $11 \%$ of the chickpea producers obtained price information from the central market before selling the produce and about $13 \%$ had market information from nearby market and central market. The sampled respondents revealed that the major source of market information were traders, radio/television, friends/ relatives, Woreda and kebeles administrations and combinations of those (Table 4).

Table 4. Access to credit of the sampled households.

\begin{tabular}{lllll}
\hline Variable & Yes & & No & \\
\hline & $\mathrm{N}$ & $\%$ & $\mathrm{~N}$ & $\%$ \\
Access to Credit & 43 & 34.96 & 80 & 65.04 \\
Access to market information & 54 & 43.9 & 69 & 56.1 \\
\hline
\end{tabular}

Source: Own survey result, 2016.

Distance to the main buyers: refers to the distance from home to the main chickpea purchase market place where they 
sold their product (chickpea). Sample chickpea producer farmers reported that they have to travel

an average $9 \mathrm{~km}$ (approximately) with corresponding standard deviations of 3.21. The minimum and the maximum distance that sampled chickpea producing respondents have to travel to nearest market centers were 4 kilometers and 18 kilometers, respectively (Table 5). In all the Keble administrations the market is available for 6 days per week, except Sunday.

Table 5. Distribution of sampled households by distance from nearest market.

\begin{tabular}{|c|c|c|c|c|}
\hline Variable & Mean & Standard deviation & Minimum & Maximum \\
\hline Distance from main buyers & $9 \mathrm{~km}$ & 3.21 & $4 \mathrm{~km}$ & $18 \mathrm{~km}$ \\
\hline
\end{tabular}

Source: Own survey result, 2016.

\section{Major Crops Produced}

As presented in Table 6 below, in the study area, chickpea is the dominant crop produced with mean 0.71 ha of area coverage and the basis of livelihood. Every farmer produces chickpea in his farm and supply to the market. Empirically, the sampled chickpea producing farmers confirmed that in addition to chickpea, they also produce other farm products like sorghum (0.2 ha), Teff (0.15ha), vegetables (0.13ha) and Maize (0.033ha) (Table 6).

Table 6. Major crops produced by sampled households during production year of 2015/16.

\begin{tabular}{lll}
\hline Types of crops & Mean hectare & Standard Deviation \\
\hline Chickpea & 0.71 & 0.30 \\
Surghum & 0.20 & 0.14 \\
Teff & 0.15 & 0.12 \\
Vegetables & 0.13 & 0.09 \\
Maize & 0.033 & 0.06 \\
\hline
\end{tabular}

Source: Own survey result 2016.

\subsection{Factors Determining Farm Households Chickpea Market Supply}

Before running the OLS regression model, all the hypothesized explanatory variables were checked for the existence of multicollinearity, omitted variable, heteroscedasticity and endogeinity problem. The study used Variance inflation factor to investigate the degree of multicollinearity among the explanatory variables. The results for all VIF values were ranging between 1.09 and 2.15 with mean value of 1.59 . Hence, multicollinearity was not a serious problem. The problem of omitted variable was tested using Ramsey RESET test. Since the p-value for this test is 0.8933 there is no omitted variable problem in the model.

In this study, heteroscedasticity was tested using BreuschPagan test for heteroscedasticity test. Due to the existence of heteroscedasticity, robust OLS regression was applied and interpreted, all the explanatory variables hypothesized were included in the model for analyzing determinants of farm households' level of market supply of chickpea.

Total of 11 explanatory variables were hypothesized to determine household level market supply of chickpea. Among the 11 hypothesized variables only five variables namely productivity of chickpea in 2015/16, size of land allocated for chickpea production, lagged price, education level and year of experience in chickpea production of the household head were found to be the significant and positive factors that determine the market supply of chickpea at household level (Table 7).

Size of land allocated for Chickpea (LD_AL_CHI): This variable was hypothesized to determine farm household level market supply of chickpea positively. The result showed that households who allocated more area of land for chickpea production had supplied more to the market. It was also found to influence the amount of chickpea supplied to the market positively and significantly at $10 \%$ significance level. The model result shows that a one hectare increase in chickpea land resulted in 3.20 quintals increase in market supply of chickpea keeping other factors constant. In support of the finding here, [9-10] indicated that the area of land allocated for sesame and cotton production in Metema District significantly and positively affected farm level market supply of sesame and cotton respectively.

Farming Experience (YR_CH_FA): The result showed that chickpea farming experience of households has positive and significant effect on chickpea quantity sold at $1 \%$ significant level. Thus, the result implied that, as farmers experience increase by one year, chickpea supplied to market increased by 0.15 quintals, keeping others factors constant. This means that the farmers with more experience in chickpea production and marketing have higher ability to sell more chickpea produce in the market than less experienced because they have more marketing network and information. This is in line with the finding of Addisu [11] who illustrated as farmers experience increased the volume of onion supplied to market increased.

Education Level (EduHH): Education has showed positive effect on chickpea quantity supplied to market with significance level of $10 \%$. The survey results revealed that, if the education level increase by one year, the amount of chickpea supplied to the market increases by 0.15 quintal, keeping other factors constant. This may be because majority of the farmers in the study area are at low level of education and thus not enable them to have better skills and better 
access to information to supply more chickpea to market. This is also in line with previous study of Ayelech [12], who found that if avocado producer gets educated, the amount of avocado supplied to the market increases. Amare [13] also reported that education level of farmers exhibited a significant and positive effect on the marketed surplus of pepper.

Chickpea productivity (YLD_2016): it was hypothesized to determine the volume of farm households' level of market supply of chickpea positively. The result indicated that households with high level of productivity had also supplied more to the market. It was also found to influence the volume of chickpea supplied at farm household level to the market positively and significantly at 5\% significance level. The model result showed that, a one quintal increase in chickpea yield resulted in 0.11 quintal increase in the volume of market supply of chickpea keeping other factors constant.
The result of this study goes along with the findings of former studies. For instance, the finding of Kindie [9], [14$15]$ found that the amount of sesame, red pepper, and coffee respectively, produced per hectare of land by household affected market supply of each of the commodities significantly and positively.

Lagged price of chickpea: it was hypothesized to determine the volume of chickpea supplied to market and found to be positive and statistically significant at 5\% significance level. The positive and significant relationship indicated that as the lagged price of chickpea increase by one birr the quantity of chickpea supplied to market also rises by 0.004 quintal the next year. In support of this the findings of Ayelech [12] on market supply of fruits found that significant positive relationship between last year fruit price and quantity of fruits supplied to the market.

Table 7. OLS results of factors affecting chickpea market supply.

\begin{tabular}{lc}
\hline Variables & Coefficient \& (Robust standard error) \\
\hline Year of experience & $0.151^{* * *}(0.029)$ \\
Sex & $0.417(0.527)$ \\
Access to market information & $-0.352(0.923)$ \\
Chickpea productivity & $0.1080 * *(0.049)$ \\
Extension & $-0.110(0.068)$ \\
Lagged price & $0.00374 * *(0.00149)$ \\
Credit & $0.096(0.913)$ \\
Education level & $0.151^{*}(0.081)$ \\
Owned oxen number & $-0.083(0.374)$ \\
Chickpea land & $3.209 *(1.862)$ \\
Constant Dependent variable=quantity supplied, $\mathrm{N}=123$, Prob $>\mathrm{F}=0.0000^{* * *}, \mathrm{R}-\mathrm{Squared}=0.54$ & $-6.299 *(3.455)$ \\
\hline
\end{tabular}

$* * *, * *, *$ shows the values statistically significant at $1 \%, 5 \%$ and $10 \%$.

F value is significant at $1 \%$ indicated that there is at least one significant explanatory variable which affect the quantity supply of chickpea at farm household level from the model.

The R-Squared $=0.54$ showed that $54 \%$ of the variation is explained by the given explanatory variables.

\section{Conclusions and Recommendations}

Ethiopia is a major chickpea producing country. However, out of the country's total area favorable for chickpea production, only about two percent is being utilized during $2015 / 16$ production season. As a result, the amount of chickpea produced in the country is low. A number of factors can determine the supply of chickpea at farm households level. In Gondar zuria Woreda, the influencing factors were productivity of chickpea in 2015/16, size of land allocated for chickpea production, lagged price, education level and year of experience in chickpea production of the household head which were found to be significantly influenced the market supply of chickpea at farm household level.

Thus, policy interventions are required to increase production and productivity of checkpea. In this respect, the following recommendations are made to increase the supply of chickpea at the farm household level in Gondar Zuria Woreda:

Econometric analysis results of the study indicated that increased productivity of chickpea resulting in market supply of chickpea. Therefore, there is a need for the concerned bodies to focus on increasing the productivity of chickpea may be through promoting and providing; improved seeds, training on production skill, technical support to farmers in agronomy practices, technical support in post-harvest.

As chickpea is the major cash crops in the study area, improving chickpea farming experience and strengthening adult education are required for the improvement of production and productivity of chickpea and to increase market supply of chickpea in the study area. Land allocated for chickpea have also a positive influence on market supplied of chickpea.

Lagged Price is also an important factor observed to influence the market supply of chickpea at farm household level. Increasing production alone is not enough without getting a reasonable selling price and marketing linkage. It is good if the concerned bodies orient chickpea traders to offer reasonable price per quintal that can inspire chickpea farmers to produce more and sell chickpea to the market for the coming year.

\section{References}

[1] CSA (Central Statistical Agency). 2016. Ministry of Finance and Economic Development. Agricultural Sample Survey on chickpea production. 
[2] FAO (Food and Agriculture Organization). 2014. Cropproduction. Availableat: http://www.faostat.faoorg.

[3] Menale Kassie, Bekele Shiferaw, Solomon Asfaw, Tsedeke Abate, Geoffrey Muricho, Setotaw Ferede, Million Eshete \& Kebebew Assefa. 2009. Current Situation and future outlooks of the chickpea sub-sector in Ethiopia. ICRISAT (Nairobi) and EIAR (Debre Zeit).

[4] Bekabil Fufa. 2004. Agricultural supply response under production risk: The case of small scale farmers in East Hararghe Zone of Oromia Regional National State in Ethiopia $\mathrm{PhD}$ dissertation, University of Pretoria.

[5] MoARD (Ministry of Agriculture and Rural Development). 2010. Federal Democratic Republic of Ethiopia

[6] Gondar Zuria Woreda Information Office, 2016. Development, Trade, View and Bather manganese (Amharic version).

[7] BOARD.2015. Bureau of Agriculture and Rural development of Gondar Zuria district.

[8] Yamane T (1967) Statistics: an introductory analysis, 2nd edn. Harper and Row, New York.

[9] Kindie Aysheshim. 2007. Sesame Market Chain Analysis: The Case of Metema Woreda, North Gondar Zone, Amhara National Regional State. An MSc Thesis Presented to the School of Graduate Studies of Haramaya University, Haramaya, Ethiopia.
[10] Bosena Tegegne. 2008. Analysis of Cotton Marketing Chains: The Case of MetemaWoreda, North Gondar Zone, Amhara National Regional State. An MSc Thesis Presented to the School of Graduate Studies of Haramaya University, Haramaya, Ethiopia.

[11] Addisu Hailu. 2016. Value Chain Analysis of Vegetables: The Case of Ejere District, WestShoa Zone, Oromia National Regional State of Ethiopia. Msc thesis presented to the school of graduate studies, Haramaya University, Haramaya, Ethiopia.

[12] Ayelech Tadesse. 2011. Market Chain Analysis of Fruits for Gomma District, Jimma ZoneOromia National Regional State. An MSc Thesis Presented to School of Graduate Studies of Haramaya University, Haramaya, Ethiopia.

[13] Amare Hounegnaw and DawitAlemu. 2013. Marketing channel and margin analysis: A case study of red pepper marketing at Jabitehinan District in Northwestern Ethiopia. International Journal of Agricultural Economics and Extension, 1 (6): 31-40.

[14] Rehima Musema. 2007. Analysis of red pepper marketing: the case of Alaba and Silitie zone in SNNPRS of Ethiopia. An MSc Thesis Presented to School of Graduate Studies of Haramaya University, Haramaya, Ethiopia.

[15] Wendmagegn Belete.2014. Market Chain Analysis of Coffee in Dale District of Southern Ethiopia. An MSc Thesis Presented to the School of Graduate Studies of Haramaya University, Haramaya, Ethiopia. 